\title{
The Effects of Student's Attitudes and Self-Efficacy on Science Achievement
}

\author{
Adiyo Roebianto \\ Faculty of Psychology, Mercu Buana University, Indonesia \\ adiyo.roebianto@mercubuana.ac.id
}

\begin{abstract}
One of the critical subjects in school that needs to be assessed is a science subject. Without a science subject, students cannot observe and understand a phenomenon on earth. However, results from an international study such as Trends International in Mathematics and Science (TIMSS), students in Indonesia performed poorly compared to students from another country. Furthermore, science is one of the essential education for children as it included in the STEM Education (Science, Technology, Engineering and Mathematics). From some empirical evidence, student's attitude and self-efficacy (beliefs about their ability and skill) were found to be dominant predictors of student's achievement, not excluded, science achievement. However, most of the research analyses the data under conventional regression analysis. Instead of under the structural modelling, and so the results can be considered carefully. This research will analyze a science achievement of Indonesian cohort, and the predictors would be self-efficacy, student's attitudes toward science, school and teaching. Five hundred seventy-six data of students would be examined path analysis to answer the research questions. The results were found that both student's attitude and self-efficacy had a significant direct role in determining student achievement in science. To be specific, attitude towards science had the most significant impact on science achievement, over self-efficacy. However, interestingly, the pattern of the effect from those predictors was different toward Science achievement. The practical aspects of the results of this study will be discussed in the discussion section.
\end{abstract}

Keywords: science achievement; attitude towards science; self-efficacy; TIMSS; path analysis

\begin{abstract}
Abstrak
Salah satu mata pelajaran penting di sekolah yang perlu dinilai adalah mata pelajaran sains. Tanpa mata pelajaran sains, siswa tidak dapat mengamati dan memahami fenomena di bumi. Namun, hasil dari studi internasional seperti Trends International in Mathematics and Science (TIMSS), prestasi sains siswa di Indonesia lebih rendah dibandingkan dengan siswa dari negara lain. Selanjutnya, sains adalah salah satu Pendidikan yang penting untuk anak-anak karena termasuk dalam Pendidikan STEM (Science, Technology, Engineering and Mathematics). Dari beberapa penelitian, sikap dan efikasi diri siswa (kepercayaan tentang kemampuan dan keterampilan mereka) ditemukan sebagai prediktor yang dominan terhadap prestasi siswa, tidak terkecuali, prestasi sains. Namun, sebagian besar penelitian menganalisis data dengan analisis regresi konvensional. Jika analisis dilakukan dengan model persamaan struktural, maka hasilnya dapat dipertimbangkan dengan hati-hati. Penelitian ini akan menganalisis prestasi sains dari siswa Indonesia, dan prediktornya adalah efikasi diri, sikap siswa terhadap sains, sekolah, dan guru. Lima ratus tujuh puluh enam data siswa akan dianalisis dengan analisis jalur (path analysis) untuk menjawab pertanyaan penelitian. Hasilnya ditemukan bahwa sikap dan efikasi diri siswa memiliki peranan langsung yang signifikan dalam menentukan prestasi siswa dalam mata pelajaran sains. Secara lebih spesifik, sikap terhadap sains memiliki dampak paling signifikan terhadap pencapaian prestasi sains, pengaruh ini lebih besar dibandingkan pengaruh dari efikasi diri. Namun, yang menarik adalah pola pengaruh dari tiap prediktor tersebut berbeda - beda dampaknya terhadap prestasi sains. Aspek praktis dari hasil penelitian ini akan dibahas pada bagian diskusi.
\end{abstract}

Kata Kunci: prestasi belajar sains; sikap terhadap sains; efikasi diri; TIMSS; analisis jalur (path analysis) 


\section{Introduction}

Science is critical knowledge in many aspects of children's daily lives. Through science education, children can understand the living, physical, material and technological components of the environment. This subject also can improve a student's logical and creative thinking. An understanding of science is necessary as society grapples with significant challenges and opportunities that confront our world.

In Indonesia, however, science is not the most favourite subject for Indonesian students. Students tend to avoid this subject in school. It is merely because most students think that science is strongly related to mathematics subject. Whenever the subject is a computational demanding and or require higher logical thinking, then students will hate it. According to the TIMSS study in 2015, student achievement in Indonesia was lower compared to other participants in the study, either in mathematics and science subjects. Even though both subjects required for human life, but Indonesian students seldom did well in these areas. The student often using mathematics function to solve a problem in the science subject. For that reason, the researcher will focus on science subject alone. Given such poor results, considerable research has sought to identify students' in- and out-of-school experiences that influence achievement and related outcomes, especially those that are alterable by policy intervention.

Science is an outstanding school subject, essential for school students to take. It is, in fact, the most important of all subjects as it allows students to question their environment to discover new things. Firstly, science is an essential school subject because it allows students to question their environment to discover new things. In science classes students are encouraged to question why things work and how they work, often carrying out experiments to find out first hand. When students come across new information, they cannot but ask and question how a particular thing works. Carefully using chemicals and observing reactions, students discover for themselves the effects of different scientific ideas. After experimenting students often set up their experiments to discover their "what if s..." putting into action their ideas and questions.

Secondly, science itself contains many aspects of the Math curriculum. Biology contains large vocabulary lists and terms that a student must have a good understanding. They use these to answer general questions just like in English. Physics takes part the mathematical side of science, incorporating numbers, calculating rates of reactions, time, motion and speed. Chemistry develops logical thinking, as students need to grasp the chemistry ideas and work out reactions to obtain a product.

By knowing the importance of science subject, several studies have been conducted to find out what the most critical aspects of increasing student achievement in science. For example, Aru (20I4) found that the typical reasons that contribute to poor performance in secondary school are a poor methodology in science education, negative attitude towards science subjects among students and lack of resources such as textbooks and well-equipped laboratories. He continued, teachers should regularly attend the in-service training to equip themselves with a new and modern methodology of teaching science subjects.

Despite the critical importance of early interest and success in science in the early grades, limited research exists on individual factors that are related to children academic achievement in the science subject. Research in science achievement has focused on the high school level. Given the significance of school performance in science in early grades, one should examine the variables such as school motivation, academic engagement, and attitude toward science and how these are related to academic success in science subjects. By the time students are in primary school, they have already made implicit decisions about pursuing or not pursuing advanced mathematics and science courses, and earlier success determines these choices. A serious examination of the factors that affect mathematics and science achievement in middle grades is critical because it is in those years that students contemplate and negotiate future trajectories. 
From the background, as mentioned earlier, the author offers some research questions as follows:

I. How is the structural relationship of science achievement with self-efficacy, attitude towards the teacher, attitude towards school, attitude towards science?

2. What is variable that have the highest impact on science achievement?

The author will investigate the relationships between science achievement and some variables such as attitude towards science, self-efficacy, under path analysis approach. Some research on science achievement had been done through non-structural regression analysis (for example, a multiple regression analysis). Under as such analysis, it is hard to understand student's performance in science comprehensively. Therefore, this research will focus on the path analysis of variables.

\section{Literature Review}

\section{Students' Attitudes and Science Achievement}

Koballa \& Glynn (2007), in their research, said that attitudes as both the facilitators and products of science learning and research efforts focused on documenting student attitudes and their relationship to science achievement. The investigation of Weinburgh \& Steele (2000) stated that attitudes are not reflections of what humans are pre-thought, but the attitudes are inferred from behaviours. In other words, a good attitude comes from right action, and conversely. According to Baldwin et al. (1999), prior knowledge and experience shape the learning process, which in turn affects a student's attitude. As a result, attitudes and beliefs of the student have become one of the targeted areas of study because some researchers have demonstrated that they play a role in how students benefit from their academic experiences, for example (Redish, Saul \& Steinberg, 1998).

Newhouse (1990) mentioned in his study that attitude was a critical factor in influencing human behaviour, including performance or achievement. Hacieminoglu (2016) said that the attitude variable was affected by personal opinion, and it caused by personal life experiences and education. Along with it, Anderson (1988) stated clearly that attitude and cognitive variables were psychological constructs that were considered to be a significant predictor of human behaviour, in this context, achievement. Related to that statement, Erkus (2003) pointed out that measuring the attitude variable and knowing the level of attitudes of individuals related to objects or circumstances are mandatory in many fields.

In this study, there are three types of attitudinal variables, namely, student attitudes towards science, student attitudes towards school and student attitudes towards the science teacher. In general, an attitude is a person's feeling positively or negatively to the enterprise of science. While Simpson \& Oliver (1990), mentioned that attitude is whether a person likes or dislikes science. That definition can be applied to any attitudinal variables.

Papanastasiou \& Zembylas (2002) found that both Science achievement and attitude toward science had a non-recursive effect. It means that both variables can affect each other, depends on the characteristics of the educational system in the country. Nasr \& Soltani (201I) found that there was a significant and little correlation between attitude towards biology and achievements in biology $(\mathrm{r}=0.12 ; \mathrm{p}<0.05)$. Baker (I985) found exciting results from his study that students who earned grade A and B in Science achievement had a negative attitude towards science. Meanwhile, students who earned low scores in Science achievement had a more positive attitude towards science.

Furthermore, Baker (1985) stated that these unexpected results could be happened due to two reasons. First, higher ability students may find science was boring at school and affected their attitude. Secondly, the instrument he used was not measuring attitude towards science. Instead, it measured another construct. 
Cannon and Simpson (1985) found that attitude accounted for I\% of student achievement in science and the ability accounted for $17 \%$ of the achievement. However, later, by the end of the semester, the ability accounted for only I0\% of the achievement, and attitude contributed 5\% slightly higher than before. Nevertheless, according to Wang \& Staver (1996), the relationships between student's attitude and Science achievement might vary from across countries, depending on their social systems and educational systems such as schools.

Kan \& Akbas (2006) found that both attitude and self-efficacy had a significant impact on science achievement. However, from their study, attitude towards science had a more significant impact on science achievement than self-efficacy itself. In another study, Anderman \& Young (1994, in Hacieminoglu, 2016) found that from Hierarchical Linear Modelling (HLM) analysis indicated there was a positive yet small correlation between students' self-efficacy and mastery goal learning $(r=.19, \mathrm{p}<.0 \mathrm{I})$. Similar results with a higher index of correlation were found in the study by Middleton \& Midgley (I997) that academic selfefficacy was related to the mastery goal learning and performance $(r=.43, p<.0 I)$. In general, those studies found that there were positive relationships between academic self-efficacy and academic achievement. However, it is not specific in science achievement.

\section{Self-Efficacy and Science Achievement}

Bandura (1986) defined self-efficacy as people's judgement of their capabilities to organise and perform a task required to achieve particular performances. Furthermore, Pintrinch \& Schunk (2002) stated that selfefficacy could be described in the question such as "Can I do this task in this situation?". Bong \& Skaalvik (2003), in their research, stated that self - efficacy represents what an individual perceives about his / her abilities and skills. Schruba (2008) identified that the value of self-efficacy lies in the students' evaluation of their views, the effectiveness of teaching and learning strategies, and the development of higher self-reported confidence in understanding science, particularly biology.

Related to science, the author identifies there is no specific research explicitly states relationship these two variables. However, Baldwin et al. (1999) noted that self-efficacy might affect a student's desire to become scientifically literate. A self-efficacy plays a vital role in student-level achievement. Joo et al. (2000) found that students' academic self-efficacy predict their performance on the given written test. Zeldin et al., (2007) stated that people are more likely perform well in the tasks they feel they can be successful and will be more likely to have higher self-efficacy when they have successful experiences.

In a general context, Pintrich \& Schraben (I992) stated that students with high self-efficacy would initiate their activities that related to study and develop learning strategies, so in turn, will likely achieve more progress and better results in science achievement. Meanwhile, students with low self-efficacy tend to not interested to involve in the learning process and consequently, they will have shallow knowledge and low academic achievement. Different results obtained from the study by Jamil \& Mahmud (2019), where they found selfefficacy has a small correlation with science achievement $(r=0.124, p>0.05)$. Furthermore, female students have higher self-efficacy $(\mathrm{M}=3.49, \mathrm{SD}=0.363)$ compared to male students $(\mathrm{M}=3.28, \mathrm{SD}-0.384)$.

Due to an emphasis on feelings and beliefs, the author considers attitude and self-efficacy affect student achievement, in this study is science subject. Schruba (2008) posits that attitudes relate to feelings; it is how student feel about science itself, either positively or negatively. Self-efficacy involves student beliefs about how "good" or "bad" they are in a particular subject. Baldwin et al. (I999) have stated about the relationship between belief, attitude and behaviour. Furthermore, Baldwin said, if a college student judges his/her ability to be lacking in science (opinion), that lack of confidence may lead to a dislike for science (attitude) and subsequent avoidance of science education (behaviour). 


\section{Instrument}

Data for this research were drawn from the Trends in International Mathematics and Science Study (TIMSS) $4^{\text {th }}$-grade student Indonesian cohort 2015. The TIMSS provides reliable and timely data on the mathematics and science achievement from the 47 participating countries, including Indonesia. TIMSS data have been collected from students at grades 4 and 8 since I995 every four years, generally. TIMSS is sponsored by the International Association for the Evaluation of Educational Achievement (IEA) (https://timssandpirls.bc.edu/).

Initially, for Indonesia cohort, the cases were 4025. However, since the research was only using booklet II and 12 , the sample size reduces become $580(\mathrm{n}=580)$. Variables that include the analysis are science achievement, self-efficacy, students' attitude towards science, students' attitude towards a teacher, students' attitude towards school. Even though the TIMSS Study has many variable levels (student, parent, teacher and school background), but due to time limitation, this study will only focus on the student level.

There were 28 items in total for measuring science achievement. Those 28 items were total of two booklets (booklet II and I2). Self-efficacy was measured by seven items with four ordinal categories (agree a lot disagree a lot). Students' attitude towards science was measured by nine items and four ordinal categories as well. Student's attitude towards teacher measured by ten items and with the same number of categories. Lastly, students' attitude towards school measured by seven items, also with four ordinal response categories.

Since the instrument used in this research from TIMSS data, the author will not check item validity. The instrument used in the TIMSS study has been well validated. Therefore, no need to further check whether the item valid or not. Even if it is needed, the detail of this application will be discussed in another article.

\section{Method}

As cited in Pedazhur \& Kerlinger (1982), path analysis was developed by Sewall Wright as a method for studying direct and indirect effects of variables hypothesised as causes of variables treated as effects. A path analysis was not intended to discover whether some variables are causing another. Instead, the path analysis was drawn from two bases that are knowledge and theoretical considerations. At least, there were two kinds of variables that can be identified in path analysis. First, an exogenous variable is one whose variation is assumed to be determined by causes outside the hypothesised model (Pedazhur \& Kerlinger, I982). This variable is used primarily to explain the endogenous variable. The endogenous variable means a variable whose variation is defined by exogenous or other endogenous variables in the model. Likewise, in regression analysis, a path analysis has some underlying assumptions. Pedazhur \& Kerlinger (1982) made the assumptions into five as follows: I) Relations among variables in the model are linear, additive, and causal. Consequently, curvilinear, multiplicative, or interaction relations are excluded; 2)Each residual is not correlated with the variables that precede it in the model; 3) There is only a one-way causal flow in the system; 4) The variables are measured on an interval scale; 5) The variables are measured without error.

In this study, science achievement was put as an outcome variable, where self-efficacy and students' attitude towards science have a direct effect on the outcome. Furthermore, students' attitude towards school affects the students' attitude towards a teacher and then affecting both students' attitude towards science and students' self-efficacy. In other words, both students' attitude towards science and self-efficacy have a direct effect. Meanwhile, students' attitude towards school and teacher have an indirect effect on the outcome variable. 


\section{Results and Discussion}

\section{Results}

Based on the results, the hypothesized model was shown fit with the data (chi-square $=20, \mathrm{df}=5$, RMSEA $=0.072$, SRMR $=0.029$, p-value $=>.05$ ). It means that the hypothesised model was not rejected (see Figure I). The Table I provides information about the regression coefficient.

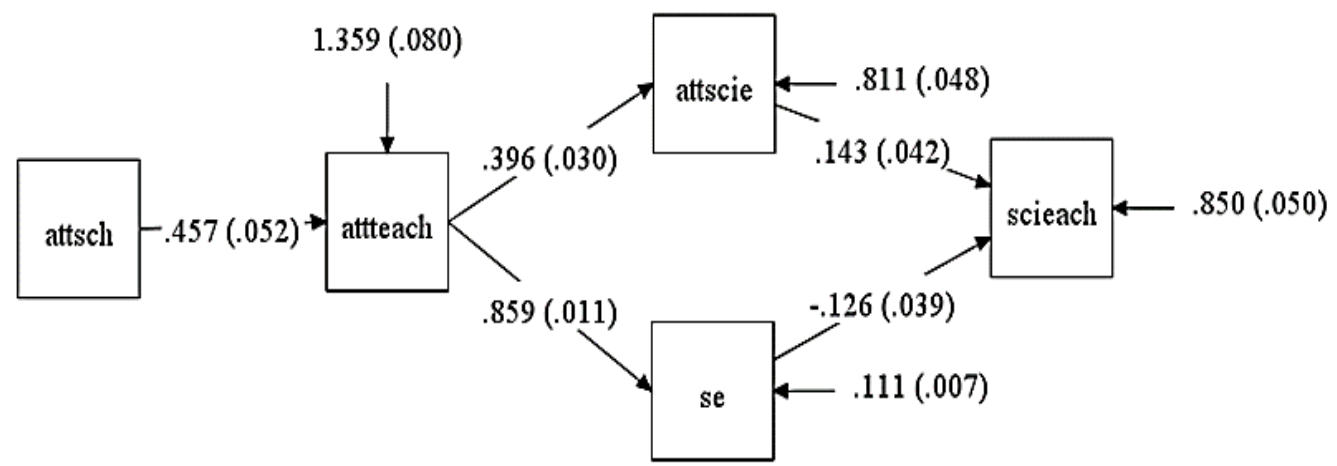

Figure I. The Result of Path Analysis of Science Achievement.

Table I. Regression Coefficients

\begin{tabular}{llllll}
\hline Variables & $\begin{array}{l}\text { Coefficient } \\
(\boldsymbol{\beta})\end{array}$ & T-value & Remarks & P-value & $\begin{array}{l}\text { Rsquare } \\
(\%)\end{array}$ \\
\hline AttScie > ScieAch &. $\mathrm{I} 43$ & 3.373 & Significant & $0.00 \mathrm{I}$ & 2.6 \\
SE $>$ ScieAch & -.126 & -3.243 & Significant & $0.00 \mathrm{I}$ & \\
AttTeach > AttScie & .396 & I3.I2I & Significant & 0.000 & 23 \\
AttTeach > SE & .859 & $76.75 \mathrm{I}$ & Significant & 0.000 & I2 \\
AttSch > AttTeach & .457 & 8.857 & Significant & 0.000 & $9 \mathrm{I}$ \\
\hline
\end{tabular}

Based on the tables above, the most substantial regression coefficient comes from the attitude towards the teacher goes to student self-efficacy, that is .859 . This coefficient was significant. Furthermore, the lowest regression coefficient was student self-efficacy towards science achievement (-.I26). However, this effect was still significant at .05. Interestingly, the effect of self-efficacy on science achievement was negative.

Even though two independent variables were having a substantial impact on science achievement, the rsquare of science achievement relatively small (2.6\% or 0.026$)$. It means that $2.6 \%$ variability in science achievement can be explained by the attitude towards science, students' self-efficacy, attitude towards schools and attitude towards teaching. Another variable should define the rest of the variability in science achievement.

Attitude towards teacher on attitude towards science was significant, with .396 of the regression coefficient. It can be said that the higher student attitude towards a teacher, the more elevated student attitude towards science. This regression was resulting in a $23 \%$ variability in student attitude towards science. Attitude towards school had a significant effect on student self-efficacy with r-square $12 \%$. Moreover, the latter path of direct impact was the attitude towards the teacher on the attitude towards school. This path was significant with .457 of regression coefficient and $91 \%$ of r-squared.

In this research, the author did not examine the direct effect of attitude towards school and teacher on science achievement. Instead, the author examines the role of attitude towards science and self-efficacy as a mediator effect of attitude towards school and teacher on science achievement. The following information is the total effect (direct and indirect effect) of all variables that go to science achievement (see Table 2): 
Table 2. Overall Effect of All Variables on Science Achievement

\begin{tabular}{|c|c|c|c|c|}
\hline Variables & $\begin{array}{l}\text { Total } \\
\text { Effect }\end{array}$ & $\begin{array}{c}\mathrm{T}- \\
\text { value }\end{array}$ & $\begin{array}{c}\mathrm{P}- \\
\text { value }\end{array}$ & $\mathrm{k}^{\text {Remar }}$ \\
\hline AttSch $>$ AttTeach > & .026 & 3.0 & 0.0 & Signifi \\
\hline AttScie $>$ ScieAch & & 9 & 00 & cant \\
\hline $\begin{aligned} & \text { AttSch }>\text { AttTeach }>\text { SE } \\
>\text { ScieAch } & \end{aligned}$ & -.05 & $\begin{array}{c}- \\
3.068\end{array}$ & $00^{0.0}$ & $\begin{array}{l}\text { Signifi } \\
\text { cant }\end{array}$ \\
\hline
\end{tabular}

Basically, there were two full main effects. Firstly, it starts from the attitude towards school goes to attitude towards a teacher then goes to attitude towards science and finally at science achievement. The second was the attitude towards school goes to attitude towards the teacher and shift to self-efficacy and finally to science achievement. Based on the results, the second path was having the highest total effect (-.05). This coefficient was significant at .05.

Furthermore, the first scheme was having .026 of the regression coefficient, and this coefficient was also significant at .05. Again, interestingly, the path comes from self-efficacy had a negative coefficient effect on science achievement. However, a different result was found from the path of students' attitude towards science. This path had a positive coefficient.

Based on these two conditions, even though the second path had a slightly more substantial impact on science achievement, yet the first path had a more rational effect on science achievement.

\section{Discussion}

From this study, it was found that attitude towards science was influencing student achievement in science positively. This finding was corresponding to previous research. For example, Carey \& Shavelson (I988) in their study was found that a positive attitude will have an impact on student achievement in science. In details, the more positive student attitude towards science, the higher student achievement in science. Moreover, eventually, performance will cause positive attitudes.

Schibeci \& Riley (1986) was examined a recursive model between science achievement and student attitude towards science. The results were supported by the model in which attitudes towards science influence performance and conversely. However, Reynolds and Walberg (1992) were found different results in their study. They have concluded that science achievement affects science attitude but not the reverse. However, in this study was only used a non-recursive model which is an attitude towards science influencing achievement in science.

Moreover, similar results were found from the study in Narmadha \& Chamundeswari (2013), that there was a positive and moderate correlation between students' attitude towards science and their academic achievement in science $(\mathrm{r}=.39, \mathrm{p}<.0 \mathrm{I})$. Also as cited earlier, Nasr \& Soltani (20I I) found a weak positive correlation between students' attitude and science achievement $(\mathrm{r}=. \mathrm{I} 2, \mathrm{p}<.05)$. These two last studies had slightly different results compared to this study, especially the way to examine the relationship among variables. These two were using a correlational analysis to test the hypothesis. However, in this study, the author used the path analysis to examine the effect of students' attitude towards science.

Another focus variable was the effect of self-efficacy on science achievement. In many studies, self-efficacy was found to be the essential factor that influences student achievement (see Reynolds \& Walberg, 1992). Self-efficacy will have a positive impact on student achievement. However, in this study, self-efficacy was found having a negative direction on the regression coefficient towards student achievement in science. This result means that the higher self-efficacy on the student, the lower student achievement in science. 
This finding is contradictory to what Bandura's wrote in his article, "perceived self-efficacy in cognitive development and functioning." (1993). He mentioned that student who believes in his/her efficacy to manage their learning and to master academic activities due to their aspirations, motivational level and academic accomplishments. Ahmad \& Triantoro (2013) found concurrent results from their study with Bandura's statements that students with higher self-efficacy will most likely obtain higher scores on the achievement test.

Similar results to the previous study, Liu, et al. (2006). found that students' self-efficacy in middle school is increasing students' achievement in science and affecting students' engagement in a computer-enhanced problem-based learning environment. However, Liu et al. found that students' attitude towards science was not a significant predictor of science achievement.

From the author's perspective, self-efficacy means that students are confident about their ability in terms of academic achievement. The worst is if the student sometimes believes that their knowledge or ability is higher than it really is. Moreover, eventually, lead them into believing that they know everything and can anything, but actually they not. In shorter words, they are just too confident about their ability.

\section{Conclusion}

The findings of this study that attitudes of the student towards science were influencing student achievement in science positively. However, a student's self-efficacy was found having a negative effect on a student's science achievement. The first finding was consistent with many researchers. However, the second one was somewhat different from many articles.

Even though those two variables were proven to be a predictor of science achievement in students, however, the effect was relatively small. It can be said that a positive attitude may increase students' achievement in science, but it does not mean so much. The author believes that most likely teachers in Indonesia are teaching their students to like or to enjoy science activities. In fact, that kind of principle does not affect so much students' performance in science.

Moreover, students should not be overestimated about their ability in science performance. In this study, most students too confident about their ability in science. However, in reality, that perception was completely wrong. In fact, the more they are confident about their ability in science, the less they performed in science. Probably, what a teacher needs to do is they should focus on mastery learning of science instead of increasing students' self-efficacy.

The main limitation of this study did not explore more the relationships between teacher and parental variables level and their impact on student achievement. In future research, it is expected that these three variables will be combined jointly to see the effects on science achievement. Also, the score of science achievement derived from all the book tests in science achievement. Hopefully, the results of this study to be considered when the stakeholders want to take decision making or even to create a new policy in education that related to student achievement.

\section{References}

Ahmad, A., \& Triantoro, S. (2013). Effects of self-efficacy on students' academic performance. Journal of Educational, Health and Community Psychology, 2, 19-25.

Anderson, L.W. (1988). Attitudes and Their Measurement Educational Research, Methodology and Measurement: An International Handbook. Editor, John P. Keeves. Pergamon Press: New York. 
Aru, J.M.K. (20I4). Factors contributing to poor performance of science subjects: a case of secondary schools in Kawe Division, Kinondoni municipality. Dissertation. The Open University of Tanzania.

Baker, D.R. (1985). Predictive value of attitude, cognitive ability, and personality to science achievement in the middle school. Journal of Science Teaching, 22(2), I03 - I I3.

Baldwin, J., Ebert-May, D., \& Burns, D. (I999). The development of a college biology self-efficacy instrument for non-majors. Science Education, 83(4), 397-408.

Bandura, A. (1986). Social foundations of thought and action: a social cognitive theory. Englewood Cliffs, NJ: Prentice-Hall.

Bandura, A. (1993). Perceived self-efficacy in cognitive development and functioning. Educational Psychologist, 28(2), II7-I48.

Bong, M., \& Skaalvik, E.M. (2003). Academic self-concept and self-efficacy: how different are they really? Educational Psychology Review, I5, I-40.

Cannon, R.K., \& Simpson, R.D. (1985). Relationships among attitude, motivation, and achievement of ability grouped, seventh-grade, life science students. Science Education, 69(2), I2I-I38.

Carey, N., \& Shavelson, R. (I988). Outcomes, achievement, participation and attitudes. In R. J Shavelson, L.M. McDonnell, \& J. Oakes (Eds.), Indicators for monitoring mathematics and science education (pp. I47 - I9I). Los Angeles, CA: Rand Corporation.

Erkus, A. (2003). Articles on psychometry. Ankara: Turkish Psychological Association Publications.

Hacieminoglu, E. (2016). Elementary school students' attitude toward science and related variables. International Journal of Environmental \& Science Education, $\operatorname{II}(2), 35$ - 52.

Jamil, N. L., \& Mahmud, S.N.D. (2019). Self-efficacy relationship on science achievement amongst national secondary school students. Creative Education, IO, 2509-2527. https://doi.org/I0.4236/ ce.2019.1011179.

Joo, Y., Bong, M., \& Choi, H. (2000). Self-efficacy for self-regulated learning, academic self-efficacy and internet self-efficacy in web-based instruction. Education Technology Research and Development, $48(2), 5-17$.

Kan, A., \& Akbas, A. (2006). Affective factors that influence chemistry achievement (attitude and selfefficacy) and the power of these factors to predict chemistry achievement-I. Journal of Turkish Science Education, 3(I), $76-85$.

Koballa, T.R., \& Glynn, S.M. (2007). Attitudinal and motivational constructs in science learning. In S.K. Abell \& N.G. Lederman (Eds.) Handbook of research on science education (pp. 75-I02). Mahwah, NJ: Lawrence Erlbaum Associates.

Liu, M., Hsieh, P., Cho, Y. \& Schallert, D. (2006). Middle school students' self-efficacy, attitudes, and achievement in a computer-enhanced problem-based learning environment. Journal of Interactive Learning Research, I7(3), 225-242.

Middleton, M., \& Midgley, C. (I997). Avoiding the demonstration of lack of ability: an underexplored aspect of goal orientation. Journal of Educational Psychology, 89, 710-718. https://doi.org/ 10.1037/0022-0663.89.4.710.

Narmadha, U., \& Chamundeswari, S. (2013). Attitude towards learning of science and academic achievement in science among students at the secondary level. Journal of Sociological Research, 4(2), I I4-I24. 
Nasr, A.R., \& Soltani, A.K. (20II). Attitude towards biology and its effects on student's achievement. International Journal of Biology, 3(4), I00-I04.

Newhouse, N. (1990). The implication of attitudes and behaviour research for environmental conservation. The Journal of Environmental Education, 22(I), 26-32.

Papanastasiou, E.C., Zembylas, M. (2002). The effect of attitudes on science achievement: a study conducted among high school pupils in Cyprus. International Review of Education 48, 469-484. https://doi.org/I0.1023/A:I02133442457I.

Pedazhur, E.J., \& Kerlinger, F.N. (1982). Multiple regression in behavioural research: Explanation and Prediction. New York: Holt, Rinehart and Winston.

Pintrinch, P., \& Schunk, D. (2002). Motivation in Education. Merill Prentice Hall.

Reynolds, A. J., \& Walberg, H. J. (1992). A structural model of science achievement and attitude: An extension to high school. Journal of Educational Psychology, 84(3), 37I-382.

Schibeci, R.A., \& Riley, J.P., Jr. (1986). Influence of students' background and perceptions on science attitudes and achievement. Journal of Research in Science Teaching, 23, 177-I87.

Schruba, A.E., (2008). Evaluation of student attitude toward science and self - efficacy in a non-majors college biology course. Thesis, Texas Christian University, Texas.

Simpson, R.D., \& Oliver, J.S. (I990). A summary of major influences on attitude toward and achievement in science among adolescent students. Science Education, 74, I-I8.

Redish, E.F., Saul, J.M., \& Steinberg, R.N. (1998). Student expectations in introductory physics. American Journal of Physics, 66(3), 212-224.

Wang, J., \& Staver, J.R. (I996). An empirical approach toward the prediction of students' science achievement in the United States and Hubei, China. Journal of Research in Science Teaching, 33, 283 - 301.

Weinburgh, M., \& Steele, D. (2000). The modified attitudes toward science inventory: developing an instrument to be used with fifth grade urban students. Journal of Women and Minorities in Science and Engineering, 6, 87-94

Zeldin, A. L., Britner, S. L., \& Pajares, F. (2007). A comparative study of the self-efficacy beliefs of successful men and women in mathematics, science, and technology careers. Journal of Research in Science Teaching, 45(9), I036-1058. https://doi.org/I0.1002/tea.20195.. 